Димитрина Лесневская

Университет национального и мирового хозяйства

Кафедра иностранных языков и прикладной лингвистики

София, Болгария

demetra3@gmail.com
УДК 81'27::371

https://doi.org/10.18485/slavistika.2019.23.1.12 оригинални научни рад примљено 04.03.2019.

прихваћено за штампу 16.05.2019.

\title{
ЭКОЛИНГВИСТИКА И ЭКОЛОГИЗАЦИЯ ОБУЧЕНИЯ ИНОСТРАННЫМ ЯЗЫКАМ
}

Статья посвящена особенностям эколингвистики и экологического образования в сфере преподавания иностранных языков. Эколингвистический подход к обучению иностранным языкам рассмотрен как глобализованный подход в рамках эколингводидактики, интегрирующий межкультурный, контрастивный, дискурсивный, социокультурный, лингвокультурологический, этнокультурный и когнитивно-прагматический подходы к иноязычному обучению. Дана характеристика таких показателей эколингвистического подхода, как экологическое сознание, экограмотность, экологическая компетентность и полиязычие.

Ключевые слова: эколингвиситка, эколингводидактика, эколингвистический подход, экологическая компетентность, экологическое сознание, экограмотность, иностранные языки, русский язык как иностранный.

The article is devoted to the particularities of ecolinguistics and ecological education in the field of foreign language teaching. The ecolinguistic approach to foreign language teaching is considered a globalized approach which integrates intercultural, contrastive, discursive, sociocultural, linguo-cultural, ethno-cultural and cognitive-pragmatic approaches to foreign language learning. The characteristics of such indicators of the ecolinguistic approach such as ecological mentality, ecological literacy, ecological competence and multilingualism are given.

Key words: ecolinguistics, ecolinguodidactics, ecolinguistic approach, ecological competence, ecological mentality, ecological literacy, foreign languages, Russian as a foreign language.

В основе современной науки эколингвистики лежит понятие «экология» (от древнегреч. oikos - «дом» и logos - «наука»). В сфере лингвистики термин «экология» появился в трудах Э. Хаугена (70-ые годы XX века), который ввел термин «эколингвистика» (ecology of language) - изучение взаимосвязи между языками в уме человека и в многоязыковом обществе. Вопросы взаимодействий языка и окружающей среды, образующих экологическую систему, были поставлены в работах М. Халлидея. В своих трудах Х. Хаарман выделяет основные факторы экологической системы: демографические, социальные, политические, культурные, психические, интеракционные и лингвистические. Ученые Р.Харре, И. Брокмайер и П. Мюльхойслер сформулировали основные тезисы эколингвистики: язык и языковые структуры входят в экологическую систему и взаимодействуют с окружающим миром; язык необходимо изучать в его естественном и культурном окружении. Предметом изучения эколингвистики является состояние языка как сложной семиотической системы, обусловленное качеством среды его обитания и функционирования, а также способы и средства защиты языка и речи от негативных воздействий, с одной стороны, и пути и средства их обогащения и развития, с другой» (Сковородников 2013). Эколингвистика ис- 
следует взаимодействие между языком, человеком как языковой личностью и его окружающей средой. Язык при этом рассматривается как неотъемлемый компонент цепи взаимоотношений между человеком, обществом и природой. Функционирование и развитие языка представляется как экосистема.

Основное направление эколингвистики сосредоточено на изучении культуры речи, стилистики и риторики и отражено в трудах, исследующих нарушения правильности, ясности, логичности, выразительности и других коммуникативных свойств речи (Кронгауз 2008), на базе которых создаются учебники и учебные пособия по культуре речи, напр.: В.И. Максимов, А.В. Голубева. Русский язык и культура речи. Учебник для бакалавров. М.: Юрайт, 2013. 382 с

Выделяются два раздела эколингвистики: экология языка и экология речи (Копнина 2014). Экология языка как системно-структурного образования и средства общения направлена на создание его экологического портрета. Составляющими экологического портрета языка являются: количество носителей языка; сферы его функционирования; внутренняя стратификация языка; наличие кодификации; вербализация в языке морально-этических концептов; негативно влияющие на развитие языка факторы и т.д. Экология речи изучает речевое поведение человека в аспекте его экологичности - качества, отражающего способность речи и текста как ее результата не наносить вред адресату. Экология языка и экология речи пересекаются в коммуникации, в частности в межкультурной коммуникации, являющейся предметом методики обучения иностранным языкам.

Современные подходы к обучению иностранным языкам базируются на личностно-ориентированной (или антропологической) парадигме в новом лингвоэкологическом аспекте. Тема экологической составляющей в содержании обучения иностранным языкам достаточно хорошо разработана в теоретическом и практическом планах (Kramsch 2008). Методология применения эколингвистического подхода к обучению иностранным языкам, в частности английскому языку как иностранному, подробно рассмотрена в работах Янины Вертлевской (Wiertlewska 2011), Сильвии Майер (Mayer et al. 2006) и др.

Эколингвистический подход к обучению иностранным языкам (ИЯ) интегрирует сравнительно-сопоставительный, дискурсивно-стилистический, этносоциокультурный, когнитивно-прагматический и межкультурный подходы к иноязычному обучению (Лесневска и др. 2018). К основным положениям современного обучения иностранным языкам В.В. Сафонова относит глобализацию, гуманизацию, экологизацию и культуроведческую социологизаицю Иностранные языки в школе 2017).

Термин «эколингводидактика» введен в научный обиход проф. В.В. Сафоновой в рамках доклада на Международном научном симпозиуме Шуменского университета им. Константина Преславского в апреле 2018 г. - г. Шумен, Болгария. Научный форум в Шумене был посвящен вопросам эколингвистики (Сафонова 2018).

В эпоху глобализации лингвистическая ситуация отличается полиязычием, поликультурностью и глубокими глобализирующими интеграционными процессами унификации. С одной стороны, это усиливает межкультурное и межъязыковое взаимодействие между языками, а с другой стороны, приводит к исчезновению национальных языков. Международными языками (англ. World Languages) считаются английский, китайский, испанский, русский и арабский. Осуществляется переход к глобальному, экологическому образованию (Scheunpflug et al. 2006). Теоретической основой экологического образования является экопедагогика, которая ставит задачу реконструкции традиционной педагогики с целью создания глобального образования в интересах устойчивого развития для создания новой экологически устойчивой цивилизации (Grigorov 2012).

Эколингвистический фактор представляет собой интегрирующий элемент в обучении ИЯ, обеспечивая диалог культур, а также целостность процесса обучения от более общего к более частному, с учетом показателей экограмотности, функциональности, экологического сознания, когнитивности, валеологичности, экологической культуры и адаптивности процесса обучения иностранному языку. Именно эколингвистический фактор является феноменом диалога культур и межкультурной коммуникации при обучении ИЯ в рамках эколингводидактики (Ульянова 2015). Экологическое сознание (этико-аксиологическое сознание) предполагает диалог с окружающей средой, формирование единства организма (общества) и внешней среды, акцентирование внимания на исконные, общечеловеческие ценности, соблюдение этических и культурологических норм. Валеологический компонент на уроках иностранного языка состоит в направленности преподавания на утверждение здорового образа жизни с целью экологического воспитания, развития экологической культуры и экограмотности обучающихся. Мотивация и энтузиазм, а также доброжелательность, терпимость, эмпатия, целостность и непрерывность являются главными условиями преподавания и обучения ИЯ (Erhart 2010). Важна также экология образовательного пространства на уроках ИЯ.

Понятие когнитивности связано с когнитивным подходом к обучению ИЯ в свете эколингводидактики. Проблематика когнитивной лингвистики отражается в ее основных категориях - концепт, концептуализация, категоризация, концептосфера или картина мира. Для эколингводидактики актуальным является тщательный отбор концептов (базовых и универсальных) и работа с ними. Картина мира является ментальной сущностью, результатом процессов концептуализации и категоризации образов мира (Одинцова 2017). Целью обучение ИЯ является формирование иноязычной концептосферы. При преподавании ИЯ в русле глобального образования важно подчеркнуть онтологичность языка, отраженность в нем физического мира и бытия духа, в котором объединяются опыт жизни народа, традиции, история, культура и абсолютные духовные ценности. Так, лингвоконцептодидактика интегрируется в рамках эколингводидактики. Применяется аксиологический подход, который предполагает изучение и преподавание языка с учетом того, что для него является исконным, изначальным ценностным основанием, глубинным содержанием языковых фактов, акцентируя на вечные ценности (Karpenko 2018). Аксиология (греч. $\alpha \xi \iota \alpha$, «стоимость», «ценность») - раздел философии, который исследует ценности и обычно подразделяется на этику и эстетику. При обучении РКИ в инославянской среде (Лесневска и др. 2018) необходимо учитывать общность славянской аксиологии (Седакова 2015).

Славистика XXIII/1 (2019) 
Эколингвистический подход предполагает обучение ИЯ, основанное на диалогическом общении. Так, специальное внимание уделяется культуре диалогической речи в соответствии с нормами общепринятого речевого этикета при преподавании русского языка как иностранного (РКИ) иностранным студентам в Украине, где проблемой является смешение русского и украинского языков в межкультурной коммуникации. При изучении речевого этикета применяется сравнительно-сопоставительный подход в комплексах упражнений, где сопоставляются русский и украинский набор фраз (Грудок-Костюшко 2018: 352)

Экологическая компетентностьпри обучении ИЯ включает в себя компетентности интегрированных подходов (межкультурная, лингвистическая, дискурсивная, лингвокультурологическая, социокультурная, этнокультурная и прагматическая компетентности) в модифицированном виде. Экологическая компетентность предполагает формирование жизненной потребности в саморазвитии и гармонии со средой и природой.

Эколингвистический подход к обучению РКИ в болгарской среде имеет свои особенности. В Болгарии русский язык изучается как инославянский, поскольку болгарский язык и русский язык - родственные славянские языки. Для оформления лингвистической компетенции на русском языке применяется контрастивный сравнительно-сопоставительный подход, при этом выделяется общая славянская лексика. Изучается русская литературно-нормированная речь как основа культуры русской речи. Согласно целям глобального образования и задачам эколингводидактики (сохранение языкового разнообразия; многоязычные компетенции; полиязычие; поликультурность; здоровье человека, общества, планеты) кроме обучения русскому языку, имеющему статус международного языка, необходимо обучение второму иностранному языку в болгарском иноязычном образовании. В настоящее время в Болгарии глобализованный эколингвистический подход к обучению иностранным языкам, в частности к обучению русскому языку, успешно осуществляется.

Целью поликультурной компетенции при обучении ИЯ в русле эколингводидактики является сохранение языкового разнообразия. В современном иноязычном образовании необходимо соблюдение принципа плюрализма, изучение полинациональной, полиэтнической культуры, воспитание толерантности к чужой культуре и ментальности. Так, в Казахстане утверждена образовательная парадигма изучения языков - Триединство языков. Эта парадигма предлагае изучение родного казахского языка и двух иностранных языков: русского и английского (Болатбаева 2015).

Эколингвистика и эколингводидактика как новые направления в лингвистической теории и практике отвечают требованиям современного глобализованного мира. Языковая политика государства строится на основе экологии языка. Проблемы эколингвистики актуальны в среде современной молодежи и вызывают тревогу и озабоченность. Речь молодого поколения до неузнаваемости обеднена, используются жаргонизированные выражения и слова-паразиты, много ненужных заимствований, что приводит к легкой манипулящии обшественным сознанием. Важное значение приобретает экологическая составляющая предметного содержания обучения ИЯ при усвоении категории бытия в учебном процессе и формировании экологического мышления и экограмотности. При
Эколингвистика и экодогизация обучения иностранным языкам

обучении иноязычной профессиональной коммуникации важно разграничение экологичной коммуникации (соблюдение речевого этикета и норм литературного языка) от неэкологичной коммуникации (клевета, диффамация, оскорбление) в рамках дискурса СМИ, юриспруденции, медицины, рекламы, официально-делового языка и др. Экологический фактор обеспечивает эффективность межкультурной коммуникации в процессе обучения иностранным языкам.

\section{Использованная литература}

Болатбаева, Аймира Т. «К вопросу о межкультурной коммуникации и полилингвизме в современном образовании». Вестник ОГПУ. Гуманитарные исследования 3(7), 2015: 94-97.

Грудок-Костюшко, Марина. «К вопросу о развитии навыков диалогической речи на занятиях по РКИ в свете эколингвистики». Русиситка 2018. Экология языка. Современная коммуникация.Шумен: Химера, 2018. 350-352.

Иностранные языки в школе, 1, 2017. Наши юбиляры. Сафонова Виктория Викторовна: 19.

Копнина, Галина А. «Экология языка и экология речи как разделы эколингвистики». Экология языка и коммуникативная практика 2, 2014:78-89.

Кронгауз, Максим. Русский язык на грани нервного срыва. М.: Языки славянских культур, 2008.

Лесневска, Димитрина С., Радослава Лесневска В. «Изучение и продвижение русского языка в Болгарии». Русистика без граници, Т.II, 1, 2018: 85-94.

Одинцова, Ирина В. «Когнитивная лингводидактика в ряду других когнитивных наук». Мир русского слова 4, 2017: 80-86.

Сафонова, Виктория В. «Учебник РКИ как инструмент межкультурной подготовки студентов: экологические и социокультурные проблемы проектирования». Русистика 2018. Экология языка. Современная коммуникация. Шумен: Химера, 2018. 388-391.

Седакова, Ирина А. «Аксиология старости в традиционной картине мира болгар (на общеславянском фоне». Категория оценки и система ценностей в языке и культуре. М., 2015.

Сковородников, Александр П. «О предмете эколингвистики применительно к состоянию современного русского языка». Экология языка и коммуникативная практика 1, 2013: 196-197.

Ульянова, Ольга Б. «Эколингвистический фактор при обучении иностранному языку». Вестник ТГУ, 2015: 75-82.

Шаховский, Виктор И. «Эмотивная лингвоэкология: комплексный подход к изучению языка, речевой деятельности и человека». Вопросы психолингвистики 1(19), 2014: 13-14.

Ehrharts, Sabine. TEMPUS IV. Linguistic Group. University of Luxembourg: 2010.

Grigorov, Stefan. «Ecopedagogy: educating for a new eco-social intercultural perspective». Visao Global. v. 15, n. 1-2, 2012: 433-454

Karpenko, Liudmila.«Axiological approach to teaching language as a factor of ecolinguistics». SocioBrains, 43, 2018: 124-127.

Славистика XXIII/1 (2019) 
Kramsch, Claire.«Ecological perspectives on foreign language education». Language Teaching, 41(3), 389-408.

Mayer, Sylvia, Wilson Gragam. Ecodidactic Perspectives on English Language, Literatures and Cultures. Trier:WVT, Wissenschaftlicher Verlag Trier, 2006.

Scheunpflug, Annette, Barbara Asbrand. «Global education and education for sustainability». Environment Education Research Vol. 12, 1, 2006: 33-46.

Wiertlewska, Janina. «Ecolinguistic approach to foreign language teaching on example of English». Glottodidactica, vol. XXXVII, 2011: 141-151.

\title{
Димитрина Лесневска
}

\section{ЕКОЛИНГВОДИДАКТИКА И ЕКОЛОГИЗАЦИЈА НАСТАВЕ СТРАНИХ ЈЕЗИКА}

\begin{abstract}
Резиме
У датом раду разматра се еколингводидактика као актуелни правац савремених лингводидактичких проучавања и екологизација наставе страних језика. Направљен је преглед претпоставки настанка и развоја еколингводидактике у окриљу савременог глобалног, еколошког образовања. Разграничавају се диференцијална обележја еколингвистичког приступа у настави страних језика, а конкретно у настави руског језика као страног у бугарској средини. Представљене су одлике глобалног образовања на нивоу конституената попут еколошког васпитања, еколошке културе, еколошког менталитета и екописмености. Настава страних језика у окриљу еколингводидактике претпоставља наставу другог страног језика у циљу достизања вишејезичности и мултикултуралности.

Кључне речи: еколингвистика, еколингводидактика, еколингвистички приступ, еколошка компетентност, еколошка свест, екописменост, страни језици, руски језик као страни.
\end{abstract}

